УДК 347.78

DOI https://doi.org/10.32837/pyuv.v0i5.928

О. С. Кочина

orcid.org/0000-0001-5625-8703

кандидат юридичних наук, доцент,

доцент кафедри публічного та приватного права та процесу Національного університету «Чернігівська політехніка»

\title{
ВИДИ ПОРУШЕНЬ АВТОРСЬКИХ ДОГОВОРІВ ТА ДОГОВОРІВ ПРО ПЕРЕДАЧУ СУМІЖНИХ ПРАВ
}

Постановка проблеми. В умовах активного розвитку сфері інтелектуальної власності договірне регулювання авторських та суміжних прав відіграє важливу роль. Договірна форма більше, ніж будь-яка інша, здатна забезпечити реалізацію й охорону як особистих, так і майнових прав суб'єктів авторського права та суміжних прав. Відповідає вона й інтересам іншої сторони, яка зацікавлена, наприклад, у гарантіях створення твору, зумовленого в замовленні, або в отриманні прибутку від реалізації права на використання твору, якого не мають інші особи. Крім того, в договірному регулюванні інтелектуальних відносин зацікавлене і суспільство, оскільки такий порядок стимулює творчу активність його членів і сприяє розвитку духовного багатства суспільства.

Аналіз судової практики свідчить, що нерідкими є випадки порушення авторських договорів та договорів про передачу суміжних прав, внаслідок чого авторам та суб'єктам суміжних прав завдається чимала шкода. У зв'язку з цим дослідження видів таких порушень та вироблення способів захисту прав суб'єктів інтелектуальної власності потребує підвищеної уваги.

Стан дослідження теми. Вибрана проблематика є малодослідженою вітчизняними науковцями. Варто виділити Т.М. Вахонєву, яка в контексті розгляду питань відповідальності за невиконання авторського договору визначає види порушень авторських договорів, але детально їх не розглядає. Дещо більшу увагу приділяють російські науковці такі, як А.П. Сергєев, С.А. Чернишева та інші. Питання порушень договорів про передачу суміжних прав взагалі залишаються недослідженими.

Метою статті є розгляд найбільш поширених способів порушень авторських договорів та договорів про передачу суміжних прав і з'ясування способів захисту суб'єктів авторського права i суміжних прав від цих порушень.

Виклад основного матеріалу. Досліджуючи наявну судову практику та особливості притягнення до відповідальності за невиконання різних видів авторських договорів, Т.М. Вахонєва виділяє такі порушення авторського договору або відхилення від його умов: 1) неправильне оформ- лення договору та включення до нього умов, які погіршують становище автора; 2) порушення умов, пов'язаних із предметом договору; 3) порушення умов, пов'язаних із реалізацією особистих немайнових та майнових прав авторів; 4) порушення умов, пов'язаних із визначенням способів та меж використання твору; 5) порушення різних видів строків авторського договору; 6) порушення договору щодо виплати авторської винагороди [1, с. 268].

Вважаємо, що зазначені види порушень притаманні також договорам про передачу суміжних прав. Отже, розглянемо кожне порушення більш детально.

1. Неправильне оформлення договору та включення до нього умов, які погіршують становище автора, виконавця, виробника фонограми, відеограми або організації мовлення. Як було зазначено вище, договори у сфері авторського права та суміжних прав за своєю юридичною природою $є$ цивільно-правовими договорами, тому недотримання загальних вимог, встановлених Цивільним кодексом (далі - ЦК) України, фактично є порушенням не самого договору, а законодавства в цій сфрері, що, як правило, має наслідком його недійсність. А з огляду на ч. 2 ст. 216 ЦК, якщо у зв' язку iз вчиненням недійсного правочину другій стороні або третій особі завдано збитків та моральної шкоди, вони підлягають відшкодуванню винною стороною [2]. Як приклад відшкодування моральної шкоди, завданої недійсним договором, можна навести ситуацію, коли правочин укладається під впливом обману (ст. 230 ЦК): замовник твору шляхом усної домовленості навмисно вводить в оману автора щодо сплати великої суми винагороди за створений твір, але потім не виконує своєї обіцянки (нагадаємо, що Законом України «Про авторське право і суміжні права» не встановлена обов'язкова письмова форма щодо договору про створення об'єктів авторського права). Або ж, коли видавець із корисливою метою укладає договір на видання твору за рахунок коштів автора, завідомо знаючи про ліквідацію видавничої організації.

Крім того, відповідно до ч. 5 ст. 33 Закону України «Про авторське право та суміжні права» 
умови договору, що погіршують становище автора (його правонаступника) порівняно зі становищем, встановленим чинним законодавством, є недійсними [3]. А згідно із ч. 1 ст. 27 ЦК правочин, що обмежує можливість фізичної особи мати не заборонені законом цивільні права та обов' язки, є нікчемним. Отже, сторони не мають змоги в договорі вказати на те, що в разі його невиконання чи неналежного виконання автор або суб'єкт суміжних прав не буде мати право на відшкодування заподіяної шкоди.

2. Порушення умов, пов'язаних із предметом договору. За своєю суттю таке правопорушення може бути вчинене лише автором, виконавцем, виробником фонограми та відеограми, організацією мовлення або їх правонаступниками, оскільки саме вони передають користувачу (замовнику) свої майнові права, що становлять предмет договору. Тобто неправомірні дії зазначених осіб щодо предмета договору можуть завдати шкоду користувачам майнових прав, наприклад, шляхом здійснення передачі прав, які їм не належать, або які вже були відчужені за договором про передачу виключних майнових прав.

3 позиції порушення прав суб'єктів авторського права та суміжних прав варто говорити про порушення умов, пов'язаних з об'єктом договору, яким можуть бути твір, виконання, фонограма, відеограма, теле-, радіопередача.

О.П. Сергєєв звертає увагу на такий вид порушення, як пошкодження або втрата користувачем твору чи матеріального носія, на якому зафіксовано твір, що буде суттєвим порушенням у тих випадках, коли разом із твором чи матеріальним носієм втрачається і сам оригінальний твір. Псування, знищення чи втрата оригіналу картини, скульптури, твору декоративного мистецтва тощо, переданого для використання замовнику, надають автору право вимагати відшкодування витрат iз реставрації твору (якщо це можливо) або оплати повної вартості оригіналу [4, с. 318]. На нашу думку, при такому правопорушенні висока вірогідність заподіяння автору або виконавцю моральних страждань та матеріальних збитків, що буде необхідною умовою для звернення до користувача з вимогою про їх відшкодування (компенсацію).

3. Порушення умов, пов'язаних із реалізацією особистих немайнових та майнових прав суб'єктів авторського права та суміжних прав. Незважаючи на те, що предметом цієї групи договорів є виключно майнові права, в процесі його виконання можуть порушуватися особисті немайнові права зазначених суб'єктів. Найбільш типовими порушеннями особистих немайнових прав є неправильне зазначення імені автора, тобто автор виявив бажання оприлюднити твір під псевдонімом, а видавництво опублікувало його під справжнім ім'ям автора, або ж незазначення імені автора чи виконавця виробником фонограми на носії запису або його упаковці, перекручування або спотворення твору, коли може бути заподіяна шкода честі та гідності автора тощо.

О.П. Сергєєв зазначає, що нерідко в процесі використання твору замовник порушує належне автору право на захист твору від спотворення, зокрема, вносить без погодження з автором зміни у твір, доповнює його додатковими елементами (коментарями, алфавітно-предметними покажчиками, ілюстраціями і т. д.). Більшість авторських договорів не встановлюють за це порушення будьяких додаткових санкцій порівняно з тими заходами захисту, які охороняють вказане право авторів незалежно від договору. У цих умовах автор може вимагати від користувача усунення виявленого порушення, відновлення цілісності твору, публікації повідомлення про порушення права, припинення використання твору в спотвореному вигляді тощо [4; с. 319].

Вважаємо, що з метою забезпечення дотримання користувачами особистих немайнових прав суб'єктів авторського права та суміжних прав, доцільно в договорах передбачати способи захисту порушених прав, у тому числі у вигляді відшкодування моральної шкоди.

Що ж стосується порушення майнових прав зазначених суб'єктів, то в разі передачі договором невиключних майнових прав, користувачі не можуть перешкоджати авторам, виконавцям, виробникам фонограм та відеограм, організаціям мовлення та їх правонаступникам розпоряджатися своїми майновими правами на власний розсуд та передавати їх третім особам.

Крім того, користувачі майнових прав не вправі передавати третім особам права на використання твору або об'єкта суміжних прав третім особам без дозволу на те автора або суб'єкта суміжних прав, якщо таке право не передбачено договором. Якщо в договорі не встановлені спеціальні санкції за такі порушення, автор або суб'єкт суміжних прав можуть захистити свої права за загальними нормами цивільного законодавства, наприклад, наряду з вимогою про відшкодування всіх заподіяних збитків вимагати від порушника компенсації моральної шкоди.

4. Порушення умов, пов'язаних із визначенням способів та меж використання твору. 3 боку користувача такі порушення можуть відбуватися в разі передання за авторським чи суміжним договором невиключних прав і можуть полягати в неправомірному використанні твору (виконання, фонограми, відеограми, телепрограми) тим способом, який не зумовлений договором або в тій частині, яка не дозволена чи не передбачена договором.

5. Порушення різних видів строків авторського та суміжного договору. Згідно із ч. 2 ст. 33 
Закону України «Про авторське право і суміжні права» строк дії авторського договору є істотною його умовою. Доречно припустити, що він є також істотною умовою договорів про передачу майнових суміжних прав. Загальний строк дії договору $\epsilon$ обов'язковим, оскільки дає змогу визначити період, протягом якого користувач, що отримує майнові права, може їх вільно використовувати.

На практиці виникають випадки, коли автори не приділяють належної уваги строку дії договору, у зв'язку з цим подають позовні заяви про захист своїх начебто порушених майнових прав. Бувають ситуації, коли видавці умисно здійснюють перевидання твору після закінчення строку дії авторського договору без отримання на те згоди автора.

Отже, строк дії договору - це ще одна умова, на яку відчужувач майнових прав (автор або суб'єкт суміжних прав) має обов'язково звертати увагу, адже через неоднозначне їі розуміння може виникнути хибна думка про порушення майнових прав. А також це дасть зазначеним особам змогу контролювати незаконні дії набувачів майнових прав, які можуть продовжувати ними користуватися після закінчення строку дії договору.

6. Порушення договору щодо виплати авторської винагороди. Розмір і порядок виплати авторської винагороди є істотною умовою авторського договору. Згідно з абз. 2 ч. 2 ст. 33 Закону України «Про авторське право і суміжні права» авторська винагорода має визначатися в договорі у вигляді відсотків від доходу, отриманого від використання твору, або у вигляді фіксованої суми чи іншим чином.

Порушення права на авторську винагороду може здійснюватися в абсолютно різних формах: 1) відмова від виплати винагороди; 2) затримання виплати винагороди; 3) зменшення розміру винагороди при скороченні обсягу твору; 4) виплата гонорару, нижчого за мінімальні ставки, що визначаються Кабінетом Міністрів України; 5) неправильний розрахунок авторського гонорару тощо [5; с. 77-78].

Варто також звернути увагу на особливості правового регулювання відносин із приводу виплати винагороди у сфері суміжних прав. За ст. 43 Закону України «Про авторське право та суміжні права» допускається використання з комерційною метою без згоди виробників фонограм (відеограм), фонограми (відеограми), і виконавців, виконання яких зафіксовані в цих фонограмах (відеограмах), але з виплатою винагороди. Виплата такої винагороди відбувається на підставі договору про виплату винагороди за використання опублікованих із комерційною метою фонограм, відеограм, їх примірників та зафіксованих у них виконань, який укладається між Уповноваженою організацією колективного управління (далі - організація) та суб'єктом комерційного використання.
Таким чином, вагому роль у захисті майнових прав авторів та суб'єктів суміжних прав, у тому числі і права на винагороду, відіграють організації колективного управління, які діють на підставі укладених, з одного боку, договорів про колективне управління майновими правами суб'єктів авторського права і суміжних прав, а $з$ іншого договорів з особами, які використовують об'єкти авторського права і суміжних прав.

Висновки. Отже, найбільш поширеними видами порушень авторських договорів та договорів про передачу суміжних прав є неправильне оформлення договору та включення до нього умов, які погіршують становище автора, виконавця, виробника фонограми, відеограми або організації мовлення, порушення умов, пов'язаних із предметом договору, порушення умов, пов'язаних із реалізацією особистих немайнових та майнових прав суб’єктів авторського права та суміжних прав, порушення умов, пов'язаних із визначенням способів та меж використання твору, порушення різних видів строків авторського та суміжного договору, порушення договору щодо виплати авторської винагороди. Для того щоб максимально захистити права авторів та суб'єктів суміжних прав, доцільно в договорах передбачати способи захисту порушених прав, зокрема у вигляді відшкодування моральної шкоди.

\section{Jimepamypa}

1. Вахонєва Т.М. Авторське право і суміжні права в Україні : навчальний посібник. Київ : ВД «Дакор», 2016. 564 c.

2. Цивільний кодекс України, прийнятий 16 січня 2003 року № 435-IV ( з под. змінами і доп.) / Верховна рада України. Відомості Верховної Ради України. 2003. № 40-44. Ст. 35.

3. Про авторське право і суміжні права : Закон України від 23 грудня 1993 р. № 3792-XII / Верховна рада України. Відомості Верховної Ради України. 1994. № 13. Ст. 64.

4. Сергеев А.П. Право интеллектуальной собственности в Российской Федерации : учебник. Изд. 2-е, переработанное и дополненное. Москва : ПБОЮЛ Гриженко Е.M., 2001. 752 с.

5. Чернышева С.А. Авторский договор в гражданском праве России. Москва : Гардарика, 1996. 104 с.

\section{Анотація}

Кочина О.С. Види порушень авторських договорів та договорів про передачу суміжних прав. - Стаття.

Стаття присвячена дослідженню найбільш поширених видів порушень авторського договору та договорів про передачу суміжних права, які трапляються на практиці. Першим із них є неправильне оформлення договору та включення до нього умов, які погіршують становище автора та суб'єкта суміжних прав. Зазначені договори за своєю юридичною природою є цивільноправовими договорами, тому недотримання загальних вимог, встановлених Цивільним кодексом України, фактично є порушенням не самого договору, а законодавства в цій сфері, що, як правило, має наслідком його недійсність. 
Порушення умов, пов'язаних із предметом договору, пов'язане із здійсненням передачі прав, які їм не належать, або які вже були відчужені за договором про передачу виключних майнових прав. Порушення умов, пов'язаних із реалізацією особистих немайнових та майнових прав авторів та суб'єктів суміжних прав. Найбільш типовими порушеннями особистих немайнових прав є неправильне зазначення імені автора, незазначення імені автора чи виконавця виробником фонограми на носії запису або його упаковці. перекручування або спотворення твору тощо. Порушення майнових прав найчастіше відбувається в процесі передачі договором невиключних майнових прав.

Також доволі поширеними порушеннями є порушення різних видів строків авторського та суміжного договору. Він є істотною умовою зазначених договорів та дає змогу визначити період, протягом якого користувач, який отримує майнові права, може їх вільно використовувати. Порушення можуть стосуватися і виплати авторської винагороди. Вона також $є$ істотною умовою авторського договору і має визначатися у вигляді відсотків від доходу, отриманого від використання твору, у вигляді фіксованої суми чи іншим чином.

Для того щоб максимально захистити права авторів та суб'єктів суміжних прав, доцільно в договорах передбачати способи захисту порушених прав, зокрема у вигляді відшкодування моральної шкоди.

Ключові слова: авторський договір, договір про передачу суміжних прав, порушення договору, строк авторського договору, авторська винагорода, відшкодування шкоди.

\section{Summary}

Kochina $O$. S. Types of violations of copyright agreements and agreements on the transfer of related rights. - Article.

The article is devoted to the study of the most common types of violations of copyright and agreements on the transfer of related rights that occur in practice. The first is the incorrect execution of the contract and the inclusion of conditions that worsen the position of the author and the subject of related rights. These agreements by their legal nature are civil law agreements, so non-compliance with the general requirements established by the Civil Code of Ukraine is in fact a violation not of the agreement itself, but of legislation in this area, which usually results in its invalidity.

Violations of the terms of the subject of the contract are usually related to the transfer of rights that do not belong to them or that have already been alienated under the contract on the transfer of exclusive property rights. Violation of the conditions related to the realization of personal non-property and property rights of authors and subjects of related rights. The most typical violations of personal non-property rights are incorrect indication of the author's name, failure to indicate the name of the author or performer by the producer of the phonogram on the recording medium or its packaging; distortion or distortion of the work, etc. Violation of property rights most often occurs when the contract transfers nonexclusive property rights.

Also quite common violations are violations of various types of terms of copyright and related agreements. It is an essential condition of these agreements and provides an opportunity to determine the period during which the user who acquires property rights can freely use them. Violations may also relate to the payment of royalties. It is also an essential condition of the copyright agreement and should be determined as a percentage of income from the use of the work, in the form of a fixed amount or otherwise.

In order to maximally protect the rights of authors and subjects of related rights, it is advisable to provide in the contracts ways to protect violated rights, including in the form of compensation for non-pecuniary damage.

Key words: copyright agreement, agreement on transfer of related rights, breach of agreement, term of copyright agreement, author's remuneration, damages. 